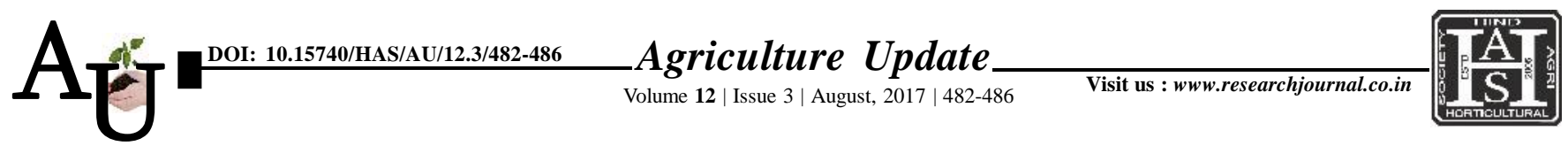

a ISSN-0976-6847

\title{
Research Article: Assessment of knowledge level of farm women regarding garment construction
}

\section{- RAJINDER KAUR SIDHU}

Article Chronicle:

Received :

07.06.2017;

Revised :

10.07.2017;

Accepted :

22.07.2017

KeY WORDS :

Farm women, Garment construction, Fabric-

silk, Salwars,

Boutiques
Author for correspondence :

RAJINDER KAUR SIDHU

Krishi Vigyan Kendra, MANSA (PUNJAB) INDIA
SUMMARY : The present study was conducted to assess the knowledge level of those farm women who had taken trainings from KrishiVigyan Kendra Mansa on garment construction. In these trainings programmes, total 108 farm women and rural girls were participated. These 108 trainees were interviewed before training and after training through questionnaire and collected data were analysed to assess their knowledge level. It was observed that before training the respondents had no knowledge regarding type of fabric- silk, taking body measurement, see print direction and layout of different parts of drafting on cloth.After getting the training on garment construction participants shows no knowledge gap or very less knowledge gap majority of the participants to gain knowledge about every aspect of stitching a garment. Stitching of suits at home on demand based and earning Rs. 3000-4000 per month. The 20.3 per cent participants do stitching of garments of boutiques at home like making salwars, doing hemming and attach laces on duppatas earning 3500-4500 per month, 11.1 per cent participants opening stitching schools in different villages and earning 5000-6000 per month and rest 7.4 per cent participants doing job in boutiques and earning 4000 per month

How to cite this article : Sidhu, Rajinder Kaur (2017). Assessment of knowledge level of farm women regarding garment construction. Agric. Update, 12(3): 482-486; DOI : 10.15740/HAS/AU/12.3/482-486. 